\title{
Kitap Değerlendirmesi: Rahile Kızılkaya Yılmaz. Çağdaş Hadis Tartışmaları ve Muvatta'. (İstanbul: iFAV Yayınları, 2020). ISBN: 9789755485126
}

\section{Elif Koç* (1)}

İlk dönem hadis edebiyatının öne çıkan eserlerinden olan Muvatta' henüz müellifi hayattayken şöhret bulmuş ve İslam coğrafyasına yayılmasıyla üzerine geniş bir literatür oluşmuştur. Gerek hadis gerek fikıh ilminin teşekkülüne dair önemli bir yere sahip bu eser, geçmiş dönemde olduğu gibi çağdaş tartışmalarda da merkezi bir konumdadır. Ancak Muvatta' etrafındaki çağdaş tartışmaların Müslümanlar tarafından uzun zaman içerisinde ortaya konan çalışmalardan temel farkı, söz konusu tartışmaların farklı bir dünya görüşü ve insan tasavvuru tarafindan şekillendirilmesidir. Bu noktada İslam geleneğinin başyapıtlarından addedilebilecek bir eser etrafında gelişen çağdaş tartışmaları bilmek, günümüz ilmî meselelerini ve bunları gündeme getiren sâikleri tanımayı da mümkün kılmaktadır.

Müellifin Muvatta'1 çalışma alanı olarak seçmesinin nedeni, onun çağdaş dönem tartışmalarının etrafında döndüğü mürsel rivâyetler bakımından zengin olması ve ilk dönem yazılı rivâyetinin önemli bir örneğini teşkil etmesidir. Böylece yazar hem isnâdın teşekkülüne hem de vasl- irsâl meselesine dair nazarî konuların rivâyet kitaplarına yansıyan boyutunu ortaya koymayı amaçlamıştır.

Yazar, kitabın "Hadis Tarihindeki Konumu Açısından Muvatta" 'başlıklı ilk bölümünde yazılış sürecinden nüsha farklılıklarına kadar Muvatta' hakkında teorik bilgiler vermektedir (s. 25- 145). "İrsâl-İttisâl” başlığını taşıyan ikinci bölümde ise oryantalist hadis tartışmalarının bel kemiğini oluşturan irsâl-ittisâl meselesi ve bununla yakından ilgili olan isnâdların geriye doğru büyümesi ve ıslahı konuları ele alınmıştır (s. 145-

\footnotetext{
* Sorumlu Yazar: Elif Koç (Arş. Gör.), Niğde Ömer Halisdemir, Üniversitesi Sosyal Bilimler Enstitüsü, Hadis Anabilim Dalı, Niğde, Türkiye. E-posta: elifkoc@ohu.edu.tr ORCID: 0000-0002-0235-086X

Atıf: Koc, Elif. "Çağdaş Hadis Tartışmaları ve Muvatta'." Rahile Kızılkaya Yılmaz'ın Çağdaş Hadis Tartışmaları ve Muvatta' adlı eserinin tanıtımı. darulfunun ilahiyat 31, 2 (2020): 491-496.

https://doi.org/10.26650/di.2020.31.2.810246
} 
274). "Muvatta'ın Mürsel Rivayetlerinden Kütüb-i Sitte'de Mevsûl Senedle Yer Alanlar" başlıklı üçüncü bölüm, önceki iki bölümde verilen teorik bilgilerin ve ortaya konan tartışmaların bir grup mürsel rivâyetin isnâd-metin analizi üzerinden uygulaması niteliğindedir.

Eser tarihlendirmesi, oryantalist camianın gündeminde olan; ancak Müslüman araştırmacılar tarafından bakir bırakılmış bir alandır. Kitap, "Muvatta'ın tarihlendirilmesi” meselesini, Türkçe literatürde tetkik eden tek müstakil çalışma olmasıyla temeyyüz etmektedir. Kitabı ayrıcalıklı kılan diğer bir nokta, irsâl-ittisâl tartışmalarına dair gerek klasik hadis edebiyatından gerek oryantalist literatürden sistematik bilgi sunmasıdır. Ayrıca yazarın oryantalist araştırmacılar arasındaki fikrî etkileşimleri ortaya koyması, bu paradigma hakkında bilgi sahibi olmayı mümkün kılmaktadır.

Kitabın ilk iki bölümünde (s. 25-274) tespit edilen teorik zeminin uygulaması mahiyetindeki üçüncü bölümde (s. 274-419) araştırmaya konu olan rivâyetler seçilirken belli bir sınırlandırmaya gidilmiştir. İrsâl-ittisâl meselesini derinlikle tetkik etme imkanı veren on bir rivâyet seçilerek bu rivâyetlerin isnâdından hareketle isnâd-metin analizi yapılmıştır. Analizde öncelikle rivâyetin Muvatta'ın nüshaları ve Muvatta 'ile muasır kaynaklarda hangi suretle yer aldığı incelenmiş, daha sonra Kütüb-i Sitte'deki mevsûl tarikleri, sened ve metin farkl1lıkları üzerinden tetkik edilmiştir. Bu çalışma sonucunda rivayetin mevsûl tarikinin mürsel varyanttan önce var olup olmadığı ya da rivâyetin hem mürsel hem mevsûl tariklerinin aynı dönemde bulunup bulunmadığına dair sorular büyük ölçüde cevaplanmış olmaktadır. Ayrıca hadisin vasledilmesinden hangi râvinin sorumlu olduğu cevaplanmaya çalışılarak ilgili rivayetin vasledilerek aktarılmasına neden olan başka sebepler üzerinde de durulmuştur. "İrsâl-ittisâl” başlıklı üçüncü bölümde seçilen rivayetler incelenirken, birinci bölümde yer verilen Muvatta'in yazılma sürecine dair iddialar ve ikinci bölümde üzerinde durulan isnâdların geriye doğru büyümesi meselesi dikkate alınarak açıklamalar yapılmıştır. Böylece kitabın bölümleri arasında tutarlılık ve mantıksal akış sağlanmıştır.

Birinci bölüm Muvatta'ın yazılma sebebine dair iddialar ile başlamaktadır. Bu iddiaları genel olarak, (I) Medine'de Muvatta'türü tasnifin başlamış olması ve İmam Mâlik'in (ö. 179/795) bu alanda kendi eserini ortaya koymak istemesi, (II) yöneticilerin İmam Mâlik’ten farklı uygulamaları birleştirmeyi sağlayacak bir kitap talep etmeleri ve (III) Medine'deki ilmî faaliyetlerin tabiî bir sonucu olarak Muvatta' in yazılması şeklinde gruplandırmak mümkündür (s. 25-245). Muvatta' 'n isimlendirilmesinin kitabın yazılış amacı hakkında fikir verebileceği ihtimali üzerinde de durulmaktadır. 
Yazar, Muvatta'ın oluşum süreci için oryantalist paradigmaya ait olan "tarihlendirme" (dating) terimini kullanmamakta ve bunun yerine "teşekkül süreci" kullanımını tercih etmektedir. Böylece yazar, oryantalistlerin inceledikleri konuyu kendi terimleri ve isimlendirmeleri üzerinden farklı bir bakış açısıyla ele aldıklarını belirtmekte ve söz konusu tefriki sağlamak üzere özelde klasik hadis literatürüne ve genel olarak da İslami ilimlere ait kavramları kullanmaktadır. Muvatta'ın yazımının başlangıç ve bitiş tarihlerine dair farklı yaklaşımları ortaya koyarken müellif, Muvatta'ın bitiş tarihiyle nüsha farklılıkları arasında ilişki kurmaktadır (s. 31).

Kitapta İmam Mâlik'in Muvatta'daki rivayetleri zamanla eleyerek azalttığı yönündeki iddia üzerinde de durulmuştur. Muvatta 'daki hadislerin zamanla İmam Mâlik tarafından azaltıldığı iddiasının mutlak doğru olmadığı ifade edilmekte ve son nüshadaki hadis sayısının fazla olması, düzenlemenin daima azalma yönünde gerçekleşmemesiyle açıklanmaktadır. "Klâsik kaynaklarda yer alan bilgiler ve Muvatta' nüshaları" başlığında Muvatta' nüshaları tek tek incelenerek nüshalar arası farkl111klar üzerinde durulmuştur.

Müellif, müstakil başlıklarda M. Zâhid el-Kevserî, (ö. 1952) 'Abdülfettâh Ebû Gudde, (ö. 1997) Muhammed Yûsuf Guraya, Umar Faruq Abd-Allāh, Halid Özkan gibi Müslüman araştırmacıların Muvatta'ın teşekkül sürecine dair görüşlerini ve oryantalistlerin iddialarını değerlendirmektedir. Bu noktada görüşler arası atıflar yapılması ve yaklaşımların karşılaştırılarak incelenmesi, iddia sahipleri arasındaki etkileşimin tespiti açısından önem arz etmektedir. Yazarın sunduğu bilgiler ışığında Muvatta' 'n oryantalistler tarafından, erken dönem hadis tarihine dair iddiaların uygulama ve delillendirme sahası olarak görüldügünü söylemek mümkündür. Bu bağlamda, müellifin Muvatta'ı merkeze alarak çalışmasını yürütmesinin, isabetli bir seçim olduğu da ortaya çıkmaktadır.

Müellif, şahıslar ve fikirler arası karşılaştırmalar yaparak, I. Goldziher-Joseph Schacht (ö. 1969)-Norman Calder (ö. 1998) çizgisi boyunca fikrî etkileşimin nasıl oluştuğu ve otorite kavramı etrafında yeniden yazılan İslam hukuk tarihi hakkında bilgi vermektedir. Bu yönüyle kitap, oryantalist yaklaşımın fikrî seyrini Muvatta ' üzerinden takip edebilmeyi sağlamaktadır. Yazarın sunduğu bilgiler ve değindiği noktalar oryantalist paradigma içindeki eleştiri anlayışının aslında temel öğreti ve yaklaşımların eleştirisi olmadığını, bilakis eleştirilerde iddialardaki eksikleri tamamlamaya yönelik yapıcı tavrın hakim olduğunu göstermesi açısından son derece ufuk açıcıdır. Ayrıca yazar, oryantalist araştırmacıların iddialarında zamanla görülen değişime yer vererek titiz ve derinlikli bir çalışma ortaya koymuştur. Müellif, çalışma boyunca oryantalist yaklaşımın her ne kadar eleştirilerle geliştirilmeye açık olsa da kendini bir gelenek olarak gördügünü ve sabit birtakım kabullerinin 
olduğunu göstermektedir. Yazarın, görüşlerini incelediği araştırmacıları süreklilik ve farkl11ık üzerinden değerlendirmesi, bu tür tespitlerin tebarüz etmesini sağladığ 1 gibi onlar arasındaki fikrî etkileşimi de ortaya koymaktadır.

Muvatta 'n bir hadis kitabı mı yoksa fikıh kitabı mı olduğu tartışmasına değinen yazar, eserin hem hadis hem fikıh kitabı özelliği taşıdığı kanaatindedir (s. 118). Hakkında hadis bulunan meselelerde İmam Mâlik' in fakih kimliğinin ikinci planda kaldığını, hadis bulunmayan konularda ise re'y ve Medine ameli üzerine bina edilmiş fakih yönünün ön planda olduğunu ifade etmektedir (s. 122).

Kitabın "İrsâl-İttisâl” başlığını taşıyan ikinci bölümünde yazar, isnâda dair görüşleriyle dikkat çeken oryantalistlerin görüşlerine yer vermektedir. İsnâd merkezli çalışmalarda oryantalistlerin gündemini meşgul eden tartışmalardan biri de isnâdın başlangıcıdır. $\mathrm{Bu}$ mesele de kitapta dikkat çeken hususlar üzerinden ele alınmış ve oryantalist yaklaşımla geleneksel İslamî yaklaşımın farkları mukayeseli bir şekilde verilmek suretiyle belirgin hale getirilmiştir. İsnâd tartışmalarına yeni bir boyut katan ve isnâdın sıhhatini değil, onun uydurulduğunu kabul ederek hangi şartlar altında oluşturulduğunu sorgulayan Goldziher'in bu kurucu rolüne dikkat çekilmiştir (s. 149-150). Müellif, Goldziher'in iddiasının analizle ulaşılmış bir netice olmadığını vurgulayarak onun isnâda belli ön kabullerle baktığını ve metin merkezli analizi esas aldığını vurgulamaktadır. Üzerinde durduğu isimlerle yazar, oryantalistler arasında isnâda yönelik farklı yaklaşımların bulunduğunu göstermiş olmaktadır. Ayrıca K. Yılmaz'ın oryantalistlerin tarihi bilgileri kullanımdaki bazı tutarsızlıklarına dikkat çekmesi son derece kıymetlidir.

İsnâdın başlangıcıyla ilgili tartışmaları dile getirdikten sonra müellif, mürsel hadis meselesini ele almaktadır. Mürsel hadisin ilk dönem eserlerindeki varlı̆̆ının, hadislerin muttasıl isnadının sonradan uydurulduğu yönündeki iddiayı geçersiz kıldığını ifade etmektedir. K. Yılmaz, 'ilel ve duafâ eserlerinin yanında cerh-tadîl ve ricâl literatürünün de irsâlin vaslı durumunu tespit ederek bunun üzerinden râvî değerlendirmesi yaptığını dile getirmektedir. Yazarın, cerh-ta'dîl ve duafâ literatüründe zikredilen isimlerin daha çok kasten mürseli vasledenleri ihtiva ederken 'ilel eserlerinin sehven vasl olgusunu inceledikleri yönündeki tespiti önemlidir. Bir sonraki bölümde müellif, cerh sebebi olarak vehmi incelemekte ve mürselin vaslı ile mevkufun merfulaşmasını da vehm altında ele almaktadır. Yazar, hadis alimlerinin mevsûlü mürsele mutlak olarak tercih etmemelerini, oryantalistlerin isnâdların mükemmelleştirildiği iddiasına cevap olarak görmektedir.

Müellif, „Şarkiyat Literatüründe İsnâdların Geriye Doğru Büyümesi ve Islâhı““ başlığında irsâl-vasl ile yakından ilgili bir konu olan isnâdların geriye doğru büyümesi iddiasını ve bu iddianın oluşumunda etkili olan oryantalist araştırmacıları 
ele almaktadır. Joseph Schacht'ın iddiayı fikri altyapıyla desteklemede merkezi bir rol üstlendiği açıktır. İsnad ile ilgili Schacht'ın temelini attığ 1 iddialar, Gualtherus H.A. Juynboll (ö. 2010) tarafından geliştirilmiştir. Juynboll'un iddialarını etraflıca aktaran yazar, „toptan bir ref“ yaşandıysa, neden o kadar çok mevkuf ve mürselin geç dönem kaynaklarında varlığını devam ettirmesine izin verilmiştir“" sorusunu yöneltmektedir.

Kitabın 'Muvatta'ın Mürsel Rivâyetlerinden Kütüb-i Sitte'de Mevsûl Senedle Yer Alanlar" başl1klı üçüncü bölümünde Muvatta 'dan seçilen on bir mürsel rivayet detaylı isnâd ve metin analizine tabi tutularak ilk iki bölümde ortaya atılan iddiaların geçerliliği tartışılmıştır. Bu bölüm eseri yalnız teorik tartışmaları nakleden hüviyetten çıkararak amelî boyutun teorik tartışmalar üzerindeki etkisini göstermesi bakımından son derece önemlidir. Yazar bu bölümü kaleme almaktaki amacını şu şekilde dile getirmiştir: „Böylece, analizin sonuçları ile ricâl ilmine dayanarak ulaşılan neticeleri karşılaştırma ve hem isnâd-metin analizi hem de ricâl ilmi hakkında bir değerlendirme yapma imkânının ortaya çıkması ümid edilmektedir“ (s. 273). Yazar, bu bölümde uyguladığı isnâd-metin analizinin, bir hadisin rivayet sürecine dair bilgi vermesi neticesinde isnâdların gerçek rivayet sürecini yansıtması nedeniyle önemli olduğunu ifade etmiştir (s. 274). Bu bölümde incelenen Muvatta 'daki mürsel rivayetlerin, Müsnedü'ş-Şâfi 'î gibi Muvatta ' ile eş zamanl eserlerde mevsûl tarikle gelmiş olması, isnâdların geriye doğru yansıtıldığı yönündeki oryantalist iddianın asılsızlığını göstermesi açısından önemlidir. Çalışmanın kıymetini artıran diğer bir özellik de incelenen isnâd ve metinlerin tablo ve şemalar vesilesiyle okuyucunun değerlendirmesine sunulmasıdır. İncelemeye konu olan hadislerdeki lafız farklı1ıkları üzerinden yazar, râvînin hadisi akranından alıp hocasına nispet etme ihtimalini değerlendirmektedir. Mürselin mevsûl tarike tercih edilmesi, oryantalistler tarafindan öne sürülen isnâdların geriye yansıtılması iddiasının isabetli olmadığını gösteren delillerdendir.

Çağdaş hadis tartışmaları ve hadis metodolojisine dair çalışmalarını Marmara Üniversitesi İlahiyat Fakültesi Hadis Anabilim Dalı'nda yürüten Rahile Kızılkaya Yılmaz'ın doktora tezini gözden geçirerek yayınladığı bu kitap, ilk dönem hadis edebiyatının ve sözlü rivayetten yazılı rivayete geçiş sürecinde kilit rol oynayan eserlerden Muvatta ' 1 inceleme konusu ederek Muvatta' etrafında geçmişte ve günümüzde ortaya atılan tartışmalara 1şık tutmaktadır. Kitapta, Muvatta 'in yazılış tarihi ve süreci, içerdiği rivayet malzemesi ve özellikle mürsel rivayetleri hakkında öne sürülen oryantalist iddialar Muvatta 'dan hareketle cevaplanmıştır. Ayrıca kitap, oryantalist araştırmacıların ve iddiaların seyrini takip etme açısından sistemli bilgi vermektedir. Kızılkaya, ricâl literatürü, 'ilel kitapları ve cerh-ta'dîl eserlerini de dahil ederek Muvatta 'daki on bir mürsel rivayet üzerine yaptığı tahlillerle, irsâl- vasl 
tartışmalarına ve isnâdların geriye doğru gelişmesi yaklaşımının değerlendirilmesine büyük bir katkı sunmaktadır. Özellikle son bölümdeki isnâd- metin analiziyle yazar, bütün alt disiplinleriyle hadis tenkid sisteminin müsned-merfû‘ hadislerle mürsel isnâdlarla nakledilenleri tespitte büyük oranda başarılı olduğunu ortaya koymuştur. Bu özellikleriyle kitap yalnız Muvatta 'üzerine çalışacak kimselere değil, hadis tarihine ve oryantalist yaklaşımları tanımaya ilgi duyan geniş bir araştırmacı kitlesine hitap etmektedir. 